\title{
Adoption of Business Process Orientation Practices: Slovenian and Croatian Survey
}

\author{
Rok Škrinjar \\ University of Ljubljana, Faculty of Economics, \\ Kardeljeva ploščad 17, 1000 Ljubljana, Slovenia \\ rok.skrinjar@ef.uni-lj.si \\ Vesna Bosilj Vukšić \\ University of Zagreb, \\ Faculty of Economics and Business, \\ Trg J.F.Kennedya 6, 10000 Zagreb, Croatia \\ vesna.bosilj@efzg.hr \\ Mojca Indihar Štemberger \\ University of Ljubljana, Faculty of Economics, \\ Kardeljeva ploščad 17, 1000 Ljubljana, Slovenia \\ mojca.stemberger@ef.uni-lj.si
}

\begin{abstract}
Process orientation has been empirically linked to corporate performance. Several studies have shown that more process oriented companies perform better than less process oriented companies. Consequently, many researchers attempted to define what makes a company process oriented, which resulted in numerous frameworks and conceptualizations of process orientation. Based on concepts of business process orientation (BPO) the authors have developed and operationalised a concept of extended BPO to study its adoption in two countries, one EU member and one a candidate for EU membership (Slovenia and Croatia, respectively). Extensive field study has been carried out in these countries. The results of the analysis show that there are many statistically significant differences, namely companies in Slovenia have implemented process oriented practices to a higher degree than their counterparts in Croatia. The paper shows the main differences in BPO areas and practices.
\end{abstract}

Keywords: business process orientation, process orientation maturity, empirical research, Croatia, Slovenia

JEL Classification: M10, L20, C83

\section{Introduction}

Business process management (BPM) projects have been unfolding intensively in global companies over the last decade. The main goal of every BPM project is to enhance a company's performance by adopting a process view of the organization. However, the implementation of a BPM concept can be a complex and time-consuming effort (Bowers, Button and Sharrock, 1995). A variety of factors influence the success of a BPM system implementation. According to Parkes (2002), an influential factor on implementation success emerging from research, trade literature and practice is the level of business process orientation (BPO) within an organization. Since BPM systems support the enactment of business processes that flow throughout the organization and across departmental borders, it may be essential that an organization's mindset values the processes themselves as tools to improve business performance (Reijers, 2006).

$\mathrm{BPO}$, and its relationship to improved cross-functional interaction, was introduced fifteen years ago by Porter (1985) and examined through the surveys conducted by Davenport and Short (1990) and Hammer (1996 and 1999). Literature review shows that there are several general definitions of BPO, but the most extended version was delivered by McCormack and Johnson (2001): "Business Process Orientation of an organization is the level at which an organization pays attention to its relevant (core) processes" (end-to-end view across the borders of departments, organizations, countries, etc.). Since many firms have adopted the business process orientation concept since, a number of surveys have been conducted to describe the results of BPO practices adoption. Following this research trend in the academic environment, we developed a joint empirical research project at the Faculty of Economics in Ljubljana and Faculty of Economics and Business in Zagreb. The goal was to investigate the understanding of the process view and process maturity levels of Slovenian and Croatian companies.

The aim of this paper is to outline the main differences in BPO areas and practices in two countries, one EU member and one a candidate for EU membership (Slovenia and Croatia, respectively). The paper is structured as follows: Firstly, the importance of business process orientation is shown (Section 2). Secondly, a detailed description of process orientation and its key aspects are presented (Section 3). Finally, the empirical study is described and the results of the analysis are shown (Section 4). The paper ends with some concluding remarks.

\section{Why is BPO important?}

Becoming process oriented offers many benefits and advantages to organizations. Regardless of the approach taken to implement process orientation (e.g. TQM, BPR, BPM...), many authors describe very similar benefits for organizations. Hammer writes that organizations can gain improvements in terms of costs, quality of products and services, speed, profitability, and other key areas if 
they focus on measuring and redesigning customer facing processes (Hammer, 2007). Hirzel (2008) cites cost reductions, cycle time reductions, more adaptable products and faster responsiveness to the changing customer needs, as key benefits of implementing process management principles.

Ligus has made more concrete statements about the outcomes of process redesign projects. According to him organizations can reduce sales costs from $30 \%$ to $35 \%$, reduce delivery time by $75-80 \%$, reduce inventory by up to $70 \%$ and realize large, but unpredictable, market share gains (Ligus, 1993). Guimaraes exposes other benefits (in addition to more general ones): reduction in office space requirements, workforce reductions, employee empowerment and improvement of their wellbeing, and improved communication between processes (Guimaraes, 1997).

Kohlbacher, based on his extensive literature review, lists the following main benefits of process orientation (Kohlbacher, 2010): speed improvements, increase of customer satisfaction, quality improvement, cost reduction, and improvement of financial performance. Hüffner groups process orientation benefits in two categories (Hüffner, 2007): quantitative (increased market share, workforce reduction, increased productivity, shorter cycle times, increased efficiency, cost reductions) and qualitative (competitive advantage, customer loyalty, flexibility, better understanding of processes, changed organizational culture).

Theoretical premises about the advantages of process orientation have also been tested in several empirical studies. McCormack and Johnson have found that increased BPO leads to increased financial performance and improved esprit de corps (McCormack and Johnson, 2001). Škrinjar et al. have expanded on McCormack's study and found that increasing process orientation maturity has a direct positive impact on non-financial performance in terms of more satisfied customers, employees and suppliers. They have also found that increased BPO impacts financial performance indirectly through non-financial performance (Škrinjar, Bosilj-Vukšić and Indihar-Štemberger, 2008).

\section{What is BPO?}

While the fact that process orientation is beneficial to organizations has been fully recognised in the field, there are still many diverse interpretations of process orientation and its constituent elements. In depth literature review reveals that various terms are being used to describe these phenomena.

\subsection{The elements of BPO}

In our review, we found 12 terms to describe the same or a very similar concept. They are:

- Horizontal corporation - Byrne, 1993

- Process centered organization - Hammer, 1996

- Process based organization - O'Connell, Pyke and Withehead, 2006; Vanhaverbeke and Torremans, 1998

- Process enterprise - Hammer and Stanton, 1999

- Horizontal organization - Daft, 2007; Day, 1999; Ostroff, 1999

- Process oriented organization - Chalikias, Valiris and Chytas, 2003; De Toro and McCabe, 1997; Kumar, Lavassani, Kumar and Movahedi, 2008; Kuwaiti and Kay, 2000; McCormack and Johnson, 2001; Sharp and McDermott, 2009

- Process focused organization - De Toro and Mc Cabe, 1997; Gardner, 2004; Neubauer, 2009

- Process driven enterprise - Fisher, 2005

- Procesna organiziranost - Kovačič and Bosilj-Vukšić, 2005

- Process managed organization - Rummler, Ramias and Rummler, 2006

- Process-centric organization - Jeston and Nelis, 2006

- Process organization - Osterloh and Frost, 2006, Kohlbacher, 2010

Definitions of BPO concept also display a significant level of diversity. Our review revealed 14 different definitions of what BPO is. As can be expected, the majority are very similar and only differ in minor aspects. Instead of citing all of them, we extracted the aspects which were included in most definitions:

- business processes have a strategic role in value creation,

- processes should be continuously improved,

- empowered inter-functional teams are the basic unit where work is performed,

- organization has a strong customer focus,

- process owners are defined and have the responsibility for the success of the processes,

- organizational structure is in line with the core process,

- process performance is measured and monitored.

The definitions of BPO that were analyzed covered different aspects of BPO but none was complete as each inherently missed at least one of the important aspects included by other definitions. Given the diversity of concepts of process orientation, it was difficult to select one definition and base our study on it. Furthermore, a study of different definitions cannot reveal the fundamental nature of process orientation, certainly not to the extent to base an empirical study on it.

To distill what BPO really is and what its constituent elements are we had to review a body of literature that deals with different elements of BPO in more depth. As the field is still immature, and many conceptualizations 
exist in parallel, our review was not limited to solely the term BPO, but also included frameworks pertaining to TQM, BPR, BPM etc. that we see as approaches to establishing BPO.

Altogether we reviewed 15 different conceptualizations of what might constitute process oriented elements. Our analysis showed that there is a strong consensus for some of the elements of BPO as most of the frameworks seem to include them. Process definition and documentation is the most important aspect of BPO as it was included in all of the reviewed frameworks. The literature also revealed a strong consensus on the organizational structure and on the measurement and management of processes.

Some elements were found only occassionally. The inclusion of the supplier's view into the framework, which was found in only 4 such frameworks, was the least common element. The inclusion of market orientation, present in only 6 frameworks, came next on the list of least frequent elements. This means that most authors focus on the internal process orientation and neglect the possibilities for future expansion of the process view to include external partners (suppliers and customers). Interestingly, the strategic view of BPO was only included in 6 frameworks, which implies that the majority of authors regard $\mathrm{BPO}$ as a means to achieve operational excellence and ignore its strategic potential for establishing a long term competitive advantage.

Altogether 9 distinct elements were detected in the 15 frameworks that were analyzed. Provided that there was at least a partial consensus on the elements, the naming of the elements was retained. In other cases, we synthetised new terms to reflect the most representative content. Our review of the 15 frameworks and 9 BPO elements is shown in table 1 below.

Table 1: Review of different conceptualizations of BPO

\begin{tabular}{|c|c|c|c|c|c|c|c|c|c|c|c|c|c|c|c|c|}
\hline ELEMENT OF BPO & 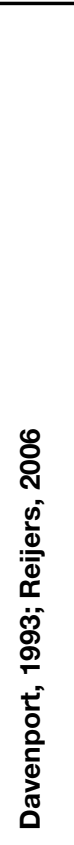 & 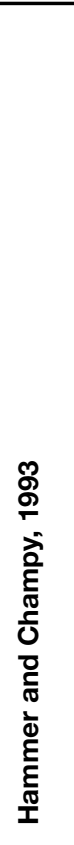 & 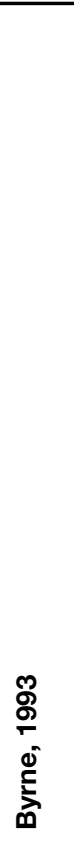 & 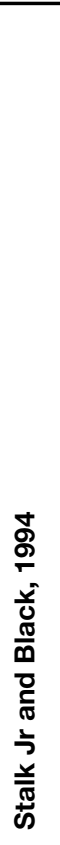 & 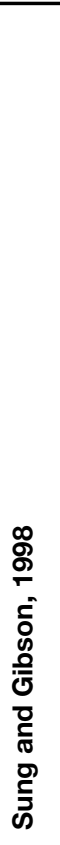 & 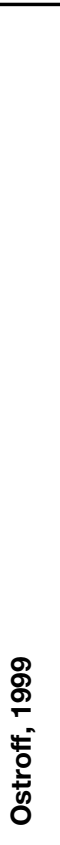 & 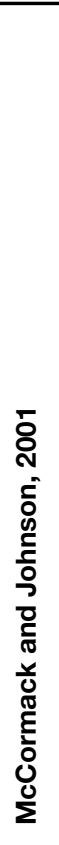 & 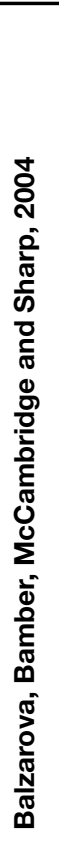 & 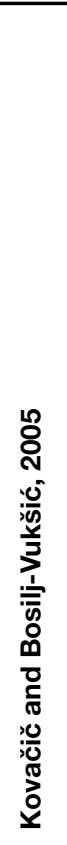 & 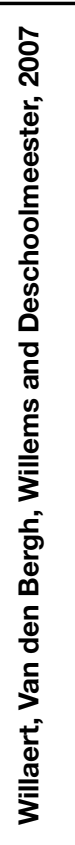 & 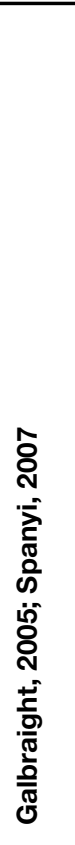 & 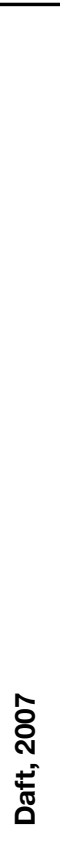 & 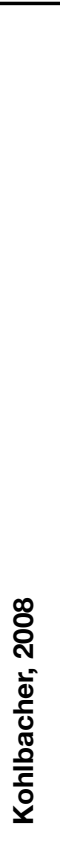 & 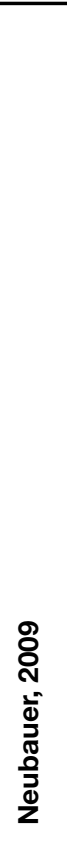 & 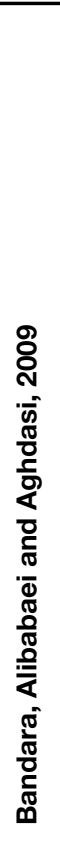 & 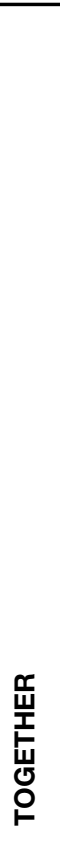 \\
\hline STRATEGIC VIEW & & 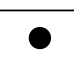 & & & $\bullet$ & & & & & & 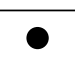 & & $\bullet$ & $\bullet$ & $\bullet$ & 6 \\
\hline $\begin{array}{l}\text { PROCESS DEFINITION } \\
\text { AND DOCUMENTATION }\end{array}$ & - & - & - & - & - & $\bullet$ & - & • & - & - & $\bullet$ & $\bullet$ & $\bullet$ & $\bullet$ & $\bullet$ & 15 \\
\hline $\begin{array}{l}\text { PROCESS MEASURE- } \\
\text { MENT AND MANAGEMENT }\end{array}$ & • & $\bullet$ & $\bullet$ & • & $\bullet$ & $\bullet$ & - & & & - & & $\bullet$ & - & $\bullet$ & $\bullet$ & 12 \\
\hline $\begin{array}{l}\text { PROCESS ORGANIZATIO- } \\
\text { NAL STRUCTURE }\end{array}$ & $\bullet$ & $\bullet$ & $\bullet$ & $\bullet$ & - & $\bullet$ & $\bullet$ & $\bullet$ & - & $\bullet$ & $\bullet$ & - & $\bullet$ & $\bullet$ & & 14 \\
\hline PEOPLE MANAGEMENT & & & $\bullet$ & & - & - & & $\bullet$ & $\bullet$ & $\bullet$ & $\bullet$ & $\bullet$ & - & & $\bullet$ & 10 \\
\hline MARKET ORIENTATION & $\bullet$ & & $\bullet$ & $\bullet$ & - & - & & & & & & $\bullet$ & & & & 6 \\
\hline SUPPLIER VIEW & & & $\bullet$ & $\bullet$ & & - & & & & $\bullet$ & & & & & & 4 \\
\hline $\begin{array}{l}\text { PROCESS ORGANIZATIO- } \\
\text { NAL CULTURE }\end{array}$ & & - & & & & - & & - & - & & & - & - & & - & 7 \\
\hline IT/IS SUPPORT & - & - & & & $\bullet$ & - & & & $\bullet$ & - & & & 0 & $\bullet$ & $\bullet$ & 9 \\
\hline
\end{tabular}


Next we will briefly present the most important aspects of all the elements of BPO that were detected in our literature review.

\section{Strategic view}

Two dominant aspects of strategic view seem to be critical:

1. the alignment of business processes with organization's strategy (Thompson, Seymour and O'Donovan, 2009; Trienekens, Kusters, Rendering and Stokla, 2005, Neubauer, 2009), possibly achieved by linking process goals to the organization goals (Harmon, 2006; Kaplan and Norton, 2004). A well-developed strategy enables optimal definition, planning and execution of business processes that implement that strategy (O'Neill and Sohal, 1998; Zairi and Sinclair, 1995).

2. active support and involvement of top management in the activities of implementing the principles of BPO into the functioning of the organization (De Bruin and Rosemann, 2006). It has been shown that, compared to projects where top management did not participate, active involvement of top management lead to higher success rates (Hall, Rosenthal and Wade, 1994).

\section{Process definition and documentation}

Excellent knowledge and understanding of internal processes is a prerequisite of process orientation (Willaert, Van den Bergh, Willems and Deschoolmeester, 2007). Aguilar-Saven claims that all successful systems start with a good understanding of the underlying processes (Aguilar-Saven, 2004) and Anderson (2007) argues that these processes need to be identified first.

Furthermore, organizations need to understand how processes work, where they are being executed and how they interconnect (Davenport, 1993; Hammer and Champy, 1993; Harmon, 2003; Tenner and DeToro, 1997). Kolbacher cites the following aspects of process definition and documentation that an organization must ensure (Kohlbacher, 2008):

- existence of a complete and uniform enterprise process model (also sometimes referred to as macro model)

- documentation of processes

- use and update of process documentation

- definition of inputs and outputs for each process

- definition of suppliers and customers for each pro cess

- existence of process cascades (internal customersupplier relationships between processes)

- segmentation of business processes if they face het erogeneous requirements.

Additionally, process documentation enables and cata- lyzes process improvements (McCormack and Johnson, 2001), helps employees in understanding how end-toend processes really work and what their role in the process is (Melan, 1989). Good process documentation is also a base for its measurement (Willaert et al., 2007).

\section{Process measurement and management}

Management and measurement are closely tied (Lebas, 1995). What is not measured cannot be managed (BosiljVukšić, Milanović, Indihar Štemberger and Škrinjar, 2008). The absence of measurement limits organization's ability to analyze the effects of changes, which inhibits systematic changes (Tenner and DeToro, 1997). Kuwaiti and Kay have shown that performance measurement is a prerequisite for process redesign as it enables the alignment of organization's processes and strategy (Kuwaiti and Kay, 2000). Similarly, Neely argues that appropriate performance indicators encourage employees to act in alignment with the strategic goals (Neely, 1999).

Two of the most frequently cited aspects of measurement and management element are:

- implementation of a process measurement syste through the definition of process goals (that need to be aligned with organization's goals), key performance indicators for these goals, setting of performance targets and continuously monitoring the efficiency and effectiveness of processes (Thompson et al., 2009),

- formalization of the process improvement practices and the usage of established methodologies and techniques that enable more successful implementa tion of new and/or changed processes (De Toro and McCabe, 1997; Raymond, Bergeron and Rivard, 1998).

\section{Process organizational structure}

As can be seen from the table above, organizational structure is one of the elements uniformly regarded as crucial. Organizational structure describes the predominating configuration of activities and tasks in organization (Skivington and Daft, 1991). Obviously, functional/ hierarchal organizational structure is not appropriate for process orientation. Some of the most cited aspects of process organizational structure are (Davenport, 1993; Hammer and Champy, 1993; Harmon, 2003; Kohlbacher, 2008; McCormack and Johnson, 2001; Neubauer, 2009; Ostroff, 1999 and many others):

- organizing work around core processes

- flatter organizational structure (fewer levels of hierarchy)

- teamwork

- employee empowerment

- jobs that involve heterogeneous task and activities, not just simple work

- process ownership 
Process orientation does not require a complete process organizational structure as it has some disadvantages as well (Daft, 2007). The final goal should not be to replace vertical structures with horizontal ones, but to find a way to intertwine the advantages of both - specialization and expertise of functional structures with responsiveness and adaptability of process structures (Stalk Jr. and Black, 1994).

\section{People management}

People management is a wide management discipline that deals with many aspects of managing people (Mathis and Jackson, 2008). With regard to process orientation, the most important aspect of people management is strategic people management that focuses on the practices connected to training and educating employees to align employee skills and knowledge with the business strategy (Becker and Huselid, 1999; Huselid, Jackson and Schuler, 1997).

Closely tied with the structural elements of process orientation, the most cited elements of people management are as follows (Hammer and Champy, 1993; Harmon, 2003; Kohlbacher, 2008; McCormack and Johnson, 2001; Ostroff, 1999; Keating, Oliva, Repenning, Rockart and Sterman, 1999; Balzarova, Bamber, McCambridge and Sharp, 2004):

- enabling employees to work in multifunctional teams,

- providing them with training and education to acquire new skills and knowledge to operate on newly defined jobs that are multidimensional, not just simple tasks,

- including and involving employees in the improvement programs, as they have the domain knowledge and will need to buy-in the new processes

- educating employees on techniques and methods of process improvement and redesign

- communicating the changes of processes to all the employees that are affected by the changes.

\section{Market orientation}

The basic goal of any process is creating value for customers (external or internal). In that regard, understanding customer needs and whishes is inextricably linked to process orientation. Organizations need to understand its customers' preferences in order to design appropriate processes that will be able to supply the output that will satisfy these preferences (Willaert et al., 2007).

Organizations must know who their customers are in the first place. They can be internal or external. Organizational goals must be focused on external customers (Tenner and DeToro, 1997; Willaert et al., 2007) and that is why it is important to identify them (Burlton, 2001). Customers can be a valuable source of information in process improvement efforts. Tonchita and Tramontano stress that customer visibility is one of the key achievements of business process management. Additionally, they point out that every employee who works in a process must be informed about end customer needs and preferences (Tonchia and Tramontano, 2004).

Knowing and understanding customers is only one part of market orientation. Organizations also need to know and understand their competition, organizations that cocreate their market and compete in it (Green Jr., Inman, Brown and Willis, 2005; Hajjat, 2002). Appropriate strategies and the underlying processes that execute them can only be set if organization combines knowledge about its customers and its competitors.

\section{Supplier perspective}

Tight cooperation with suppliers is also one of the key elements of process orientation (Možina, Rozman, Glas, Tavčar, Pučko, Kralj et al., 2002) as organization's processes can span outside its borders and are tightly connected to suppliers' processes (Willaert et al., 2007). In that regard process optimization cannot be optimal if suppliers' processes are disregarded. Clearly, organization does not have an impact on suppliers' processes if the cooperation is transaction based. On the other hand, forming long-term relationships with its suppliers offers more possibilities for a joint and coordinated redesign of processes that span several organizations.

\section{Process organizational culture}

Changing organization to process oriented represents a vast change in the way business is conducted. In that sense, organizational culture plays an important role in organization's ability to change (Balzarova et al., 2004; Bandara, Alibabaei, Aghdasi, 2009; Daft, 2007; Hammer and Champy, 1993; Kohlbacher, 2008; Kovačič and Bosilj-Vukšić, 2005; Ostroff, 1999; Willaert et al., 2007).

Key values and aspects of organizational culture that are most often cited in literature with regard to implementing process orientation are (Ahadi, 2004; Balzarova et al., 2004; Daft, 2007; Kohlbacher, 2008; Love and Gunasekaran, 1997; McCormack and Johnson, 2001; Reijers, 2006; Sung and Gibson, 1998; Thompson et al., 2009):

- shared vision and purpose,

- openness and cooperation,

- creativity and positive attitude of employees,

- usage of appropriate process terminology (input, output, process owner etc.),

- employee empowerment and their inclusion in deci sion making,

- flexibility,

- goal orientation,

- employees' understanding that they work for end customers. 


\section{IT/IS process support}

The role of IT in process redesign has long been stressed as one of the more important aspect of redesign efforts (Ahadi, 2004; Al-Mashari and Zairi, 1999; Armistead and Rowland 1996; Belmonte and Murray, 1993; Black and Porter, 1996; Davenport, 1993; Davenport and Short, 1990; De Bruin and Rosemann, 2006; Groznik and Kovačič, 2003; Hall et al., 1994; Hammer and Champy, 1993; Harmon, 2003; Kohlbacher, 2008; Kovačič and Bosilj-Vukšić, 2005; O'Neill and Sohal, 1998; Tenner and DeToro, 1997; Willcocks and Smith, 1995; Zairi and Sinclair, 1995 and many others). Combination of process redesign and utilization of appropriate IT/IS support can drastically improve business processes (Kung and Hagen, 2007; Love and Gunasekaran, 1997).

Even though many authors stress the importance of IT/ IS in redesign efforts, its role can be very different at different stages of the redesign. Kovačič and Bosilj-Vukšić (2005) define three roles: 1) creating new needs and opportunities (new products and services); 2) process redesign support; 3) process execution support. Eardley and coauthors define six different roles of IT/IS: 1) constraint; 2) catalyst; 3) neutral; 4) driver; 5) enabler and 6) proactive (Eardley, Shah and Radman, 2008).

While the role of IT/IS in implementing BPO is clearly diverse, there seems to be a consensus on one aspect. Namely that only a carefully considered combination of process redesign efforts coupled with appropriate IT/ IS support offers the most beneficial potential to organizations embarking on transformation path (Kung and Hagen, 2007). Kung and Hagen (2007) have found that utilizing process oriented information systems and the principles of process management in combination yields most noticeable increase in quality and success of individual processes.

Having presented our extended BPO framework and its constituting elements we now turn to the empirical study that was carried out to analyze to what extent different aspects of process orientation were present in organizations and to discover potential areas for improvement.

\subsection{Process orientation maturity}

$\mathrm{BPO}$ is not a bipolar concept. Rather, companies evolve through various levels of process orientation maturity. The notion of maturity has been proposed in other management approaches as a way to evaluate "the state of being complete, perfect, or ready" and the "fullness or perfection of growth or development" (Oxford English Dictionary, 2010). Maturity in itself does not happen instantaneously; rather, it is a path. Likewise, BPO maturity in organizations evolves through stages or levels of maturity as organizations adopt more and more BPO practices. Many maturity models have been developed in an attempt to define these stages. Such models can facilitate the evolution as they describe a path to maturity (Spanyi, 2007).

For the purpose of this paper we adopt McCormack's and Johnson's maturity model. The stages undergone by an organization as it becomes business process oriented are defined below:

- Ad Hoc: The processes are unstructured and ill defined. Process measures are not in place and the jobs and organizational structures are based upon the traditional functions, not horizontal processes.

- Defined: The basic processes are defined and documented and are available in flow charts. Changes to these processes must now go through a formal procedure. Jobs and organizational structures include a process aspect, but remain basically functional. Representatives from functions (sales, manufacturing, etc.) meet regularly to coordinate with each other, but only as representatives of their traditional functions.

- Linked: The breakthrough level. Managers employ process management with strategic intent and results. Broad process jobs and structures are put in place outside of traditional functions.

- Integrated: The Company, its vendors and suppliers, take cooperation to the process level. Organizational structures and jobs are based on processes, and traditional functions begin to be equal or sometimes subordinate to process. Process measures and management systems are deeply imbedded in the organization (McCormack and Johnson, 2001).

\section{Empirical study}

In 2008 a joint empirical research was carried out by Faculty of Economics staff in Croatia and Slovenia. The main goal was to assess the current state of BPO practices and BPO maturity of companies in both countries as well as to analyze the possible differences between the two countries.

In order to carry out the empirical study we developed a new questionnaire. It contained 53 questions regarding BPO characteristics. The questions were distributed across the 9 domains presented in the theoretical part of the paper: Strategic view (5 questions), Process identification and documentation (6 questions), Process measurement and management (7 questions), Process oriented organizational structure (5 questions), Human resources management (5 questions), Process oriented organizational culture (6 questions), Market orientation (7 questions), Supplier perspective (3 questions), Process oriented information technology (7 questions). Each question describes a particular BPO characteristic and/ or business practice considered important within each domain. The degree of presence of these characteristics in the organization of a firm is measured on a 7 point Lik- 
ert scale (1=Strongly disagree, 2=Disagree, $3=$ Disagree more than agree, 4=Neither agree or disagree, 5=Agree more than disagree, $6=$ Agree, 7 =Strongly Agree).

Questionnaires were sent to CEOs or senior managers in 3089 firms (1750 Croatian and 1339 Slovenian). A total of 195 Croatian and 129 Slovenian managers responded, so the final response rate was $10.5 \%$. Company size was determined by the number of employees and its annual revenues. The distribution of companies in our sample is shown in figure below (Figure 1).
However, Slovenian companies are, on average, closer to level 3, whereas Croatian companies are, on average, positioned in the middle of level 2. Even though the values do not differ greatly, the difference was found to be statistically significant $(t=3.726, p<0.005)$. This means that Slovenian companies are slightly more process-oriented than their Croatian counterparts, which was expected considering the geopolitical situation of Croatia in the past $15-20$ years. Consequently, compared to the Slovenian companies, the Croatian companies started the transformation process with a time delay.

Figure 1: Frequency of companies by number of employees and annual revenues

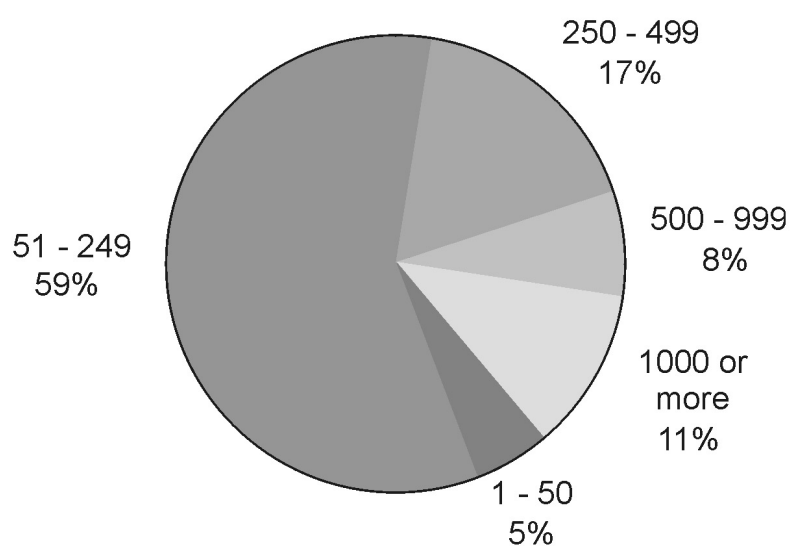

The most common sort of business in the data set is Manufacturing (36.8\%). It is followed by Construction (10.3\%), Trade (7.8\%) and Catering industry (5.9\%). $39.2 \%$ of the companies were involved in other sorts of business.

\subsection{Data analysis - global}

The data gathered from the two national samples was analyzed using descriptive statistics and the independent samples t-test. Statistic analysis revealed the differences and similarities with regard to process orientation practices in the two countries. Analysis results are shown below.

Firstly, the compound measure of the BPO construct was analyzed, which revealed the overall state of business process orientation for both countries. Because a seven-point Likert scale was used, the following cut points were set: level one includes companies that attained average BPO scores from 1 to 4; level two includes companies with average BPO scores from 4 to 5.5; level three includes companies with average BPO scores between 5.5 and 6.5; and level four includes companies with average BPO scores between 6.5 and 7 . Based on the two samples, the compound measure of the BPO is $\mathbf{5 . 2 2}$ for Slovenia and $\mathbf{4 . 8 5}$ for Croatia ${ }^{1}$. Both values fall into level 2 of business process orientation maturity.

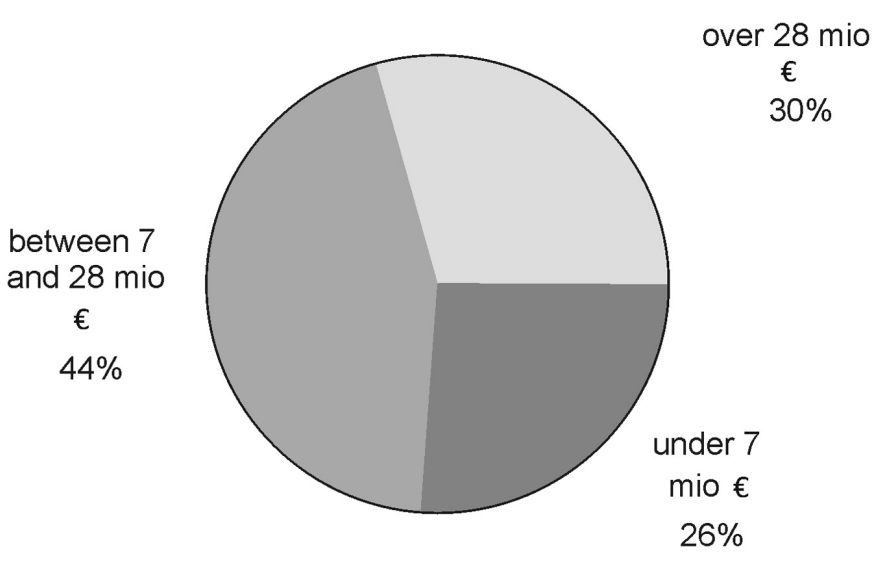

To determine the underlying reasons for the differences in the attained maturity level, the individual elements as well as their internal practices need to be analyzed in depth. The descriptive statistics of individual responses are shown in table 3 . In order to identify areas where more significant differences are found we will first focus our analysis on the level of BPO elements. The results of the analysis are shown in table 2 : the number of practices included in the questionnaire for each element of BPO (second column), the number of the practices where statistically significant differences were found in two national samples (third column) and the percentage of practices that have been found to be statistically significantly different within each BPO element (fourth column).

Most differences were found in the people management element. All practices analyzed were found to be statistically significantly different. The companies in Slovenia have implemented appropriate people management practices, those that support process orientation, to a larger degree than those in Croatia. Market orientation element also exhibited profound differences in the degree of implemented practices. In 6 out of 7 practices the Croatian companies lagged behind the Slovenian ones. Many statistically significant differences were also found in process measurement and management element as well as in process organizational culture element. 
The least differences were detected in process organizational structure element, where only one practice was significantly different; the companies in Slovenia have implemented it to a higher degree. Also, only few statistically significant differences were found in supplier view element and IT/IS support element. Altogether 29 (55\%) out of 53 practices were found to be significantly view. Namely, process descriptions (models) are much less frequently available to all employees in the Croatian than in the Slovenian companies. This finding confirms that there is a lack of communication in the Croatian companies. Process descriptions serve many functions and should be available to all employees at all times.

Table 2: Number of statistically significant differences in each element of BPO

\begin{tabular}{llll} 
& $\begin{array}{l}\text { number of key } \\
\text { practices included } \\
\text { in element }\end{array}$ & $\begin{array}{l}\text { number of statistically } \\
\text { significant differences in } \\
\text { individual practice mean } \\
\text { score }\end{array}$ & $\begin{array}{l}\text { percentage of } \\
\text { statistically significant } \\
\text { differences }\end{array}$ \\
\hline STRATEGIC VIEW & 5 & 2 & $40 \%$ \\
\hline PROCESS DEFINITION AND DOCUMENTATION & 6 & 3 & $50 \%$ \\
\hline PROCESS MEASUREMENT AND MANAGEMENT & 7 & 5 & $71 \%$ \\
\hline PROCESS ORGANIZATIONAL STRUCTURE & 7 & 1 & $14 \%$ \\
\hline PEOPLE MANAGEMENT & 5 & 5 & $100 \%$ \\
\hline PROCESS ORGANIZATIONAL CULTURE & 6 & 4 & $67 \%$ \\
\hline MARKET ORIENTATIO & 7 & 6 & $86 \%$ \\
\hline SUPPLIER VIEW & 3 & 1 & $33 \%$ \\
\hline IT/IS SUPPORT & 7 & 2 & $29 \%$ \\
\hline
\end{tabular}

different. The lower compound BPO score of the Croatian companies is therefore the result of the general and scattered pattern of underutilized practices across the entire framework of BPO. In the rest of the paper we present and analyze the areas of the largest differences.

\subsection{Analysis by practices}

In Table 3 below the results of independent samples $t-$ test are presented. Here we will discuss only the most important differences within each element. Starting with the strategic view element, two practices are adopted to a higher degree in the Slovenian companies. The largest difference was found in Asv4 (please see appendix for the complete list of practices and codes). In the Slovenian companies policy and strategy are more frequently communicated and cascaded throughout the organization. This is a very important aspect of any change initiative as employees need to be informed and educated on organization's initiatives. If BPO implementation initiative stays within the confines of top management the probability of its success will be low. The Croatian companies should invest more effort in explaining and communicating their strategies to their employees. Uninformed employees will otherwise be inclined to resist change solely from the fear of unknown. The benefits of BPO should be clearly articulated and presented.

In process definition and documentation element $50 \%$ of the practices were significantly different. The difference is the largest with respect to Addp5, which is very much in line with the findings on the adoption of a strategic
As regards process measurement and management, all of the exemplary practices are more developed in the Slovenian companies. The largest difference was detected for Ammp3. It pertains to the operationalization of performance measurement system in that the performance targets are set for all process goals. The Slovenian companies have implemented this practice to a higher degree than their Croatian counterparts. It should be stressed that process measurement and management hinge on Ammp3 as it is the practice that makes the measurement system usable and useful. Without knowing what the company wants to achieve in specific measures, it is impossible to measure the company's progress and success.

In process organizational structure element only one practice implementation was significantly different. It was found that in the Slovenian companies jobs are not just simple tasks, that they are more frequently multidimensional. Process orientation typically requires that employees' work tasks and responsibilities are broadened to reduce the number of handoffs between employees, increase execution time and reduce mistakes.

People management element is where the Croatian companies were lagging behind on all practices. Most notably on Auk1: workers in the Croatian companies learned new things on their jobs much less frequently then their Slovenian counterparts. On the one hand, this shows that training programs are underdeveloped., On the other hand, processes may not be changing all that frequently so people don't need to learn new skills. Both 
interpretations seem plausible and suggest more work needs to be done in these areas: educating and training employees and improving processes on a continuous base. Another practice within this category that surfaced as a great differentiator between the two countries was Auk4. It was found that employees in the Croatian companies are not held accountable for delivering on the professed goals as often as the Slovenian employees. This is in line with a finding in measurement and management element, were it was stressed that targets are usually not set in the Croatian companies. Clearly, if targets are not set, they cannot be measured and performance cannot be assessed. If performance is not assessed no one can be held accountable. Again, setting targets and appointing responsibility should be on the Croatian companies' priority list.

Process organizational culture was more developed in the Slovenian companies (67\%), as exhibited by a more process oriented understanding of the way companies operate in Slovenia (Apok2) and the more frequent usage of typical process terminology by the Slovenian employees (Apok1). The differences in the attained level of these two practices between the studied countries were found to be the largest within the element. Getting people to understand the process principles, to see how processes really work from end-to-end is one of the more important aspect of BPO implementation. When they have this understanding, the usage of process terminology usually increases naturally. Again, there seems to be a problem with a lack of communication and unavailability of process descriptions to all employees in the Croatian companies. It is also strongly connected to the people management element whereby training programs for employees to learn how processes work should be created.

In the market orientation element, most differences between the Slovenian and Croatian companies arise from the level of understanding customer needs and preferences (Atu1, Atu2) and designing products and services based on these preferences (Atu5). This is problematic since processes should be designed to create value for customers. In other words, the output should satisfy customers' needs. Not understanding customers' needs and consequently not designing products and services based on these needs results in suboptimal processes. The first order of business should therefore be to scan the market, understand the needs, communicate them to employees and design products and processes that will satisfy them.

In supplier view element and IT/IS support element the fewest differences were found and are not discussed further here.

\section{Conclusion}

The main goal of our study was to determine whether there are differences in BPO adoption between Croatian and Slovenian companies. The data from the empirical study that has been subjected to relevant statistical techniques has shown that the Slovenian companies have reached a slightly higher BPO maturity level than the Croatian companies. While the Slovenian companies are more close to level 3 of BPO maturity, the Croatian companies are, on average, in the middle of level 2. These results should be put into the context of Croatian contemporary history. Besides, the results of this survey could be used as a guideline for the improvement of $\mathrm{BPO}$ in both countries.

The contribution of this paper is two-fold: first BPO elements were systemized and analyzed in order to propose an extended BPO framework and its constituting elements. This BPO framework can serve managers as a road map of specific steps that will lead to the BPM maturation of that specific enterprise. Companies will continue looking for new strategies for survival in tough times. Therefore, BPM must evolve from a mere methodology into a holistic management discipline that takes an integrated approach to the organisation and its business as a whole. We belive that the discussion in this paper will stimulate BPM practitioners and academic researchers to sign up for the next phase of collaboration upon $\mathrm{BPO}$ issues.

Second, the empirical results of our research outline the most prominent issues and challenges faced by companies that have made the choice to implement BPM. Hence, these results have many practical implications for managers of the Slovenian, but especially of the Croatian companies. They need to examine their current managerial practices, organizational structures, organizational culture and communication, and measurement practice. According to the results of the survey, it is of a great importance for the Croatian companies to increase the efforts in stimulating employees across the organisation to care about the bigger picture, collaborate across departments to realise the common goals, and constantly consider how their work might impact the work of others. Croatian top managers should develop a framework of decision-making structures, roles and processes that is conducive to multidimensional organisational change and interaction across boundaries. Besides, they must become aware of the need to infuse their BPM approaches with a customer focus, taking on an outside-in perspective on the organisation's business processes. Regardeless the difference between Croatian and Slovenian BPO maturity level, both countries still face the great challenge of transforming their companies into process oriented ones. 
Table 3: Independent samples t-test results

\begin{tabular}{|c|c|c|c|c|c|c|c|}
\hline \multirow{2}{*}{$\begin{array}{l}\text { practice } \\
\text { code }\end{array}$} & \multicolumn{3}{|c|}{ Levene's Test for Equality of Variances } & \multicolumn{4}{|c|}{ t-test for Equality of Means } \\
\hline & Equal variances? & $\mathrm{F}$ & Sig. & $t$ & $\mathrm{df}$ & Sig. (2-tailed) & Mean Difference \\
\hline Asv1 & No & 8.301 & .004 & 1.228 & 320.265 & .220 & .154 \\
\hline Asv2 & No & 12.287 & .001 & 1.241 & 311.824 & .215 & .165 \\
\hline Asv3 & No & 12.241 & .001 & 3.737 & 311.411 & .000 & .590 \\
\hline Asv4 & No & 17.294 & .000 & 4.162 & 310.113 & .000 & .640 \\
\hline Asv5 & Yes & 3.014 & .084 & -1.518 & 319 & .130 & -.230 \\
\hline Addp1 & No & 4.350 & .038 & 1.886 & 244.386 & .061 & .352 \\
\hline Addp2 & No & 9.156 & .003 & .924 & 309.218 & .356 & .138 \\
\hline Addp3 & No & 9.806 & .002 & 1.682 & 314.627 & .094 & .262 \\
\hline Addp4 & No & 8.987 & .003 & 2.752 & 317.978 & .006 & .398 \\
\hline Addp5 & No & 11.006 & .001 & 3.741 & 306.793 & .000 & .710 \\
\hline Addp6 & No & 17.296 & .000 & 2.562 & 305.552 & .011 & .452 \\
\hline Ammp1 & Yes & 3.206 & .074 & 2.115 & 319 & .035 & .382 \\
\hline Ammp2 & Yes & .171 & .680 & 1.167 & 320 & .244 & .204 \\
\hline Ammp3 & No & 14.299 & .000 & 3.352 & 313.884 & .001 & .564 \\
\hline Ammp4 & No & 7.247 & .007 & 3.467 & 296.857 & .001 & .617 \\
\hline Ammp5 & No & 9.255 & .003 & 2.873 & 305.429 & .004 & .485 \\
\hline Ammp6 & Yes & 3.011 & .084 & 1.509 & 314 & .132 & .272 \\
\hline Ammp7 & No & 10.129 & .002 & 3.205 & 304.838 & .001 & .538 \\
\hline Apos1 & No & 13.606 & .000 & 3.719 & 319.668 & .000 & .562 \\
\hline Apos2 & No & 22.939 & .000 & 1.673 & 316.108 & .095 & .217 \\
\hline Apos3 & No & 8.261 & .004 & .928 & 309.309 & .354 & .158 \\
\hline Apos4 & Yes & 3.253 & .072 & .783 & 302 & .435 & .150 \\
\hline Apos5 & Yes & .502 & .479 & -.635 & 286 & .526 & -.149 \\
\hline Apos6 & Yes & .442 & .507 & -1.086 & 318 & .278 & -.184 \\
\hline Apos7 & Yes & 2.013 & .157 & .077 & 317 & .939 & .015 \\
\hline Auk1 & No & 12.653 & .000 & 4.596 & 322.737 & .000 & .695 \\
\hline Auk2 & No & 15.383 & .000 & 2.719 & 312.464 & .007 & .413 \\
\hline Auk3 & No & 22.661 & .000 & 3.048 & 319.111 & .002 & .467 \\
\hline Auk4 & No & 11.944 & .001 & 3.899 & 321.362 & .000 & .596 \\
\hline Auk5 & Yes & .012 & .914 & 2.523 & 326 & .012 & .515 \\
\hline Apok1 & Yes & 1.997 & .159 & 4.370 & 320 & .000 & .936 \\
\hline Apok2 & No & 24.922 & .000 & 4.580 & 315.640 & .000 & .793 \\
\hline Apok3 & Yes & .272 & .602 & .618 & 321 & .537 & .114 \\
\hline Apok4 & No & 16.690 & .000 & 1.356 & 310.137 & .176 & .196 \\
\hline Apok5 & No & 11.292 & .001 & 2.116 & 317.404 & .035 & .332 \\
\hline Apok6 & No & 21.598 & .000 & 2.634 & 320.238 & .009 & .392 \\
\hline Atu1 & No & 10.790 & .001 & 3.166 & 304.257 & .002 & .577 \\
\hline Atu2 & No & 26.625 & .000 & 3.060 & 322.787 & .002 & .391 \\
\hline Atu3 & No & 23.516 & .000 & 2.522 & 321.924 & .012 & .340 \\
\hline Atu4 & No & 4.683 & .031 & 1.915 & 300.538 & .056 & .362 \\
\hline Atu5 & No & 25.600 & .000 & 3.806 & 321.396 & .000 & .488 \\
\hline Atu6 & No & 16.740 & .000 & 2.275 & 313.671 & .024 & .339 \\
\hline Atu7 & No & 6.918 & .009 & 2.089 & 300.292 & .038 & .359 \\
\hline Avd1 & No & 4.803 & .029 & .381 & 303.305 & .703 & .051 \\
\hline Avd2 & Yes & 1.758 & .186 & .390 & 324 & .697 & .063 \\
\hline Avd3 & No & 5.116 & .024 & 2.367 & 290.312 & .019 & .440 \\
\hline Apit1 & No & 8.900 & .003 & 1.792 & 295.638 & .074 & .323 \\
\hline Apit2 & No & 6.257 & .013 & 1.973 & 307.875 & .049 & .332 \\
\hline Apit3 & No & 10.252 & .002 & 1.138 & 301.872 & .256 & .200 \\
\hline Apit4 & Yes & .012 & .914 & 1.227 & 307 & .221 & .289 \\
\hline Apit5 & No & 13.362 & .000 & 6.310 & 292.778 & .000 & 1.406 \\
\hline Apit6 & Yes & 1.066 & .303 & $\begin{array}{l}-.686 \\
\end{array}$ & 319 & .493 & -.163 \\
\hline Apit7 & Yes & 1.123 & .290 & .641 & 315 & .522 & .140 \\
\hline
\end{tabular}


While the presented research findings are comprehensive in content, research could be expanded much further. Namely, other countries could be included in the study to illuminate the state of BPO in different environments. Additionally, a longitudinal study may yield interesting results: the same companies could be surveyed periodically to assess their progress on the road to BPO maturity.

\section{References}

1. Aguilar-Saven, R. S. (2004). Business Process Modelling: Review and Framework. International Journal of Production Economics, 90(2), 129-149.

2. Ahadi, H. R. (2004). An Examination of the Role of Organizational Enablers in Business Process Reengineering and the Impact of Information Technology. Information Resources Management Journal, 17(4), 1-19.

3. Al-Mashari, M., Zairi, M. (1999). BPR implementation process: an analysis of key success and failure factors. Business Process Management Journal, 5(1), 87-112.

4. Andersen, B. (2007). Business Process Improvement Toolbox (2 ed.). Milwaukee: American Society for Quality.

5. Armistead, C., Rowland, P. (1996). Managing Business Processes - BPR and Beyond. Chichester: Wiley.

6. Balzarova, M. A., Bamber, C. J., McCambridge, S., Sharp, J. M. (2004). Key success factors in implementation of process-based management: A UK housing association experience. Business Process Management Journal, 10(4), 387-399.

7. Bandara, W., Alibabaei, A., Aghdasi, M. (2009, September 2009). Means of achieving Business Process Management success factors. Paper presented at the 4th Mediterranean Conference on Information Systems, Athens.

8. Becker, B. E., Huselid, M. A. (1999). Overview: Strategic human resource management in five leading firms. Human Resource Management, 38, 287-301.

9. Belmonte, R. W., Murray, R. J. (1993). Getting Ready for Strategic Change - Surviving Business Process Redesign. Information Systems Management, 10(3), 23-29.

10. Black, S. A., Porter, L. J. (1996). Identification of the Critical Factors of TQM. [Article]. Decision Sciences, 27(Winter96), 1-21.

11. Bosilj-Vukšić, V., Milanović, L., Indihar Štemberger, M., Škrinjar, R. (2008). Organizational performance measures for business process management: a performance measurement guidelin. EUROSIM/ UKSim2008, 94-99.

12. Bowers, J., Button, G. and Sharrock, W. (1995). Workflow from within and without: technology and cooperative work on the print industry shopfloor. In Marmolin, H., Sunblad, Y. and Schmidt, K. (Ed.), Proceedings of European Conference on ComputerSupported Cooperative Work (pp. 51-66). Kluwer, Stockholm

13. Burlton, R. (2001). Business process management: profiting from process. Sams.

14. Byrne, J. A. (1993). The Horizontal Corporation. Business Week (3351), 76-81.

15. Chalikias, K., Valiris, G., Chytas, P. (2003). The Role of IT in Business Process-Oriented Organizations. Operational Research. An International Journal, 3(2), 137-154.

16. Daft, R. L. (2007). Understanding the Theory and Design of Organizations. Manson: Thomson SouthWesteren.

17. Davenport, T. H. (1993). Process Innovation: Reengineering Work Through Information Technology. Boston: Harvard Business School Press.

18. Davenport, T.H, Short, J.E. (1990). The new industrial engineering: information technology and business process redesign. Sloan Management Review, 31, 11-27.

19. Day, G. (1999). Aligning Organizational Structure to the Market. Business Strategy Review, 10(3), 33.

20. De Bruin, T., Rosemann, M. (2006). Towards Understanding Strategic Alignment of Business Process Management. Paper presented at the 17th Australasian Conference on Information Systems.

21. De Toro, I., McCabe, T. (1997). How to stay flexible and elude fads. Quality Progress, 30(3), 55.

22. Eardley, A., Shah, H., Radman, A. (2008). A model for improving the role of IT in BPR. Business Process Management Journal, 14(5), 629-653

23. Fisher, D. M. (2005). Getting Started on the Path to Process - Driven Enterprise Optimization. BPTrends, February 2005, 1-8. On line article, http://www. bptrends.com/publicationfiles/02-05\%20ART\%20 Process\%200ptimizationi\%20-\%20Fisher.pdf

24. Galbraight, J. R. (2005). Designing the customercentric organization: a guide to strategy, structure and process (1 ed.): Jossey-Bass.

25. Gardner, R. (2004). The Process-focused Organization: A Transition Strategy for Success. Milwaukee, WI: ASQ Quality Press.

26. Green Jr, K. W., Inman, R. A., Brown, G., Willis, T. $H$. (2005). Market orientation: relation to structure and performance. [Article]. Journal of Business \& Industrial Marketing, 20, 276-284.

27. Groznik, A., Kovačič, A. (2003). The Real Business Value of IT. Economic and Business Review, 5(1-2), 137-146.

28. Guimaraes, T. (1997). Empirically testing the antecedents of BPR success. International Journal of Production Economics, 50(2-3), 199-210.

29. Hajjat, M. M. (2002). Customer orientation: construction and validation of the CUSTOR scale. Marketing Intelligence and Planning 20(7), 428-441. 
30. Hall, E. A., Rosenthal, J., Wade, J. (Writer) (1994). How to make reengineering really work [Article], McKinsey Quarterly: McKinsey \& Company, Inc.

31. Hammer, M. (1996). Beyond Reengineering: How the Process-centered Organisation is Changing Our Work and Our Lives. NY: HarperCollins, New York.

32. Hammer, M. (2007). The Process Audit. Harvard Business Review, April 2007, 111-123.

33. Hammer, M. (1999). How process enterprises really work. Harvard Business Review, (NovemberDecember), 108-118.

34. Hammer, M. (1996). Beyond Reengineering: How the Process-Centered Organization is Changing Our Lives. New York, NY: HarperBusiness.

35. Hammer, M., Champy, J. (1993). Reengineering the Corporation: A manifesto for Business evolution. New York: Harper Business Press.

36. Hammer, M., Stanton, S. (1999). How process enterprises really work. Harvard Business

37. Harmon, P. (2006). Process and strategy. Business Process Trends: Monthly E-mail Advisors, 4(6)

38. Harmon, P. (2003). Business Process Change: A Manager's Guide to Improving, Redesigning, and Automating Processes. San Francisco: Morgan Kaufman Publishers.

39. Hirzel, M. (2008). Prozessmanagement in der Praxis: Wertschöpfungsketten planen, optimieren und erfolgreich Steuern. Gabler Verlag.

40. Hüffner, T. (2007). The BPM Maturity Model- Towards A Framework for assessing the Business Process Management Maturity of Organisations. GRIN Verlag.

41. Huselid, M. A., Jackson, S. E., Schuler, R. S. (1997). Technical and strategic human resource management effectiveness as determinants of firm performance. Academy of Management Journal, 39, 949- 969.

42. Jeston, J., Nelis, J. (2006). Business Process Management: Practical Guidelines to Successful Implementations. Oxford: Elsavier.

43. Kaplan, R. S., Norton, D. P. (2004). The strategy map: guide to aligning intangible assets. Strategy and Leadership, 32(5), 10-17.

44. Keating, E., Oliva, R., Repenning, N., Rockart, S., Sterman, J. (1999). Overcoming the improvement paradox. European Management Journal, 17(2), 120-134.

45. Kohlbacher, M. (2010). The effects of process orientation: a literature review. Business Process Management Journal 16(1), 135-152.

46. Kohlbacher, M. (2008). Process Orientation of Manufacturing Companies. Paper presented at the GBDI Tenth International Conference

47. Kovačič, A., Bosilj-Vukšić, V. (2005). Management poslovnih procesov: Prenova in informatizacija poslovanja. Ljubljana: GV Založba d.o.o.

48. Kumar, U., Lavassani, K. M., Kumar, V., Movahedi, B. (2008). Measurement of Business Process Orientation in Transitional Organizations: An Empirical
Study. Business Information Systems, 357-368.

49. Kung, P., Hagen, C. (2007). The fruits of Business Process Management: an experience report from a Swiss bank. Business Process Management Journal, 13(4), 477-487.

50. Kuwaiti, M. E., Kay, J. (2000). The role of performance measurement in business process reengineering. International Journal of Operations \& Production Management, 20(12), 1411-1426.

51. Lebas, M. J. (1995). Performance measurement and performance management. International Journal of Production Economics, 41(1-3), 23-35.

52. Ligus, R. G. (1993). Methods to help reengineer your company for improved agility. Industrial Engineering, 25(1), 59-59.

53. Love, P. E. D., \& Gunasekaran, A. (1997). Process reengineering: A review of enablers. International Journal of Production Economics, 50(2-3), 183197.

54. Mathis, R. L., Jackson, J. H. (2008). Human Resource Management. Manson: Thomson South-Western.

55. McCormack, K. P., Johnson, W. C. (2001). Business process orientation - Gaining the e-business competitive advantage. Florida: St. Lucie Press.

56. Melan, E. H. (1989). Process management: a unifying framework for improvement. National Productivity Review, 8(4), 295-406.

57. Možina, S., Rozman, R., Glas, M., Tavčar, M., Pučko, D., Kralj, J., et al. (2002). Management: Nova Znanja za Uspeh (1 ed.). Radovljica: Didakta.

58. Neely, A. (1999). The performance measurement revolution: why now and what next? International Journal of Operations \& Production Management, 19(2), 205-228.

59. Neubauer, T. (2009). An empirical study about the status of business process management. Business Process Management Journal, 15(2), 166-183.

60. O'Connell, J., Pyke, J., Withehead, R. (2006). Mastering Your Organizaation's Processes: A Plain Guide to Business Process Management (1 ed.). Cambridge: Cambridge University Press.

61. O'Neill, P., Sohal, A. S. (1998). Business process reengineering: application and success--an Australian study. International Journal of Operations \& Production Management, 18(9/10), 832-864.

62. Osterloh, M., Frost, J. (2006). Prozessmanagement als Kernkompetenz. Wiesbaden: Gabler.

63. Ostroff, F. (1999). The Horizontal Organization. Oxford: Oxford University Press.

64. Parkes, A. (2002). Critical success factors in workflow implementation. Proceedings of the 6th Pacific Asia Conference on Information Systems, Jasmin, Tokyo, 363-80.

65. Porter, M.E. (1985). Competitive Advantage: Creating \& Sustaining Superior Performance. New York, NY: The Free Press.

66. Raymond, L., Bergeron, F., Rivard, S. (Writer) (1998). Determinants of business process reengineering 
success in small and large enterprises: An [Article]. Journal of Small Business Management, WileyBlackwell.

67. Reijers, H.A. (2006). Implementing BPM systems: the role of process orientation. Business Process Management Journal, Vol. 12 No. 4, pp. 389-409

68. Review, November/December, 108-118.

69. Rummler, G. A., Ramias, A. J., Rummler, R. A. (2006). Potential Pitfalls on the Road to a Process Managed Organization (PMO): Part 1: The Organization as System Lens. BPTrends, November 2006, 1-13

70. Sharp, A., McDermott, P. (2009). Workflow Modeling: Tools for Process Improvement and Application Development. Norwood, MA: Artech House.

71. Skivington, J. E., Daft, R. L. (1991). A study of organizational framework and process modalities for the implementation of business-level strategic decisions. Journal of Management Studies, 28(1), 45-68.

72. Spanyi, A. (2007). More for Less: The Power of Process Management. Tampa: Meghan-Kiffer Press.

73. Stalk Jr, G., Black, J. E. (1994). The myth of the horizontal organization. Canadian Business Review, 21(4), 26.

74. Sung, T. K., Gibson, D. V. (1998). Critical Success Factors for Business Reengineering and Corporate Performance: The Case of Korean Corporations. Technological Forecasting and Social Change, 58(3), 297-311.

75. Škrinjar, R., Bosilj-Vukšić, V., \& Indihar-Štemberger, M. (2008). The impact of business process orientation on financial and non-financial performance. Business Process Management Journal, 14(5), 738 - 754.

76. Tenner, A. R., DeToro, I. J. (1997). Process redesign: the implementation guide for managers. Reading (Mass.) [etc.]; Harlow (Essex); Addison Wesley Longman: Addison-Wesley.

77. Thompson, G., Seymour, L. F., O'Donovan, B. (2009). Towards a BPM Success Model: An Analysis in South African Financial Services. Organizations Enterprise, Business-Process and Information Systems Modeling, 1-13.

78. Tonchia, S., Tramontano, A. (2004). Process management for the extended enterprise: organizational and ICT networks. Berlin: Springer.

79. Trienekens, J. J. M., Kusters, R. J., Rendering, B., Stokla, K. (2005). Business-oriented process improvement: practices and experiences at Thales Naval The Netherlands (TNNL). Information and Software Technology, 47(2), 67-79.

80. Vanhaverbeke,W., Torremans, H. (1998). Organizationl Structure in Process-based Organization. Paper presented at the 14th EGOS-Conference.

81. Willaert, P., Van den Bergh, J., Willems, J., Deschoolmeester, D. (2007). The Process-Oriented Organisation: A Holistic View Developing a Framework for Business Process Orientation Maturity. In G.
Alonso, P. Dadam, M. Rosemann (Ed.), Business Process Management (pp. 1-15). Berlin: SpringerVerlag.

82. Willcocks, L., Smith, G. (1995). IT-enabled business process reengineering: organizational and human resource dimensions. The Journal of Strategic Information Systems, 4(3), 279-301.

83. Zairi, M., Sinclair, D. (1995). Business process reengineering and process management: A survey of current practice and future trends in integrated management. Business Process Management Journal, 1(1), 8-30. 
Apendix

Practice coding table

\begin{tabular}{|c|c|}
\hline Code & Practice \\
\hline Asv1 & Top management is actively involved in process improvement efforts. \\
\hline Asv2 & Business (sub)process goals are derived from and linked to the organization's strategy. \\
\hline Asv3 & $\begin{array}{l}\text { Business process improvement and redesign is frequently on the agenda of top management } \\
\text { meetings. }\end{array}$ \\
\hline Asv4 & Policy and strategy are communicated and cascaded throughout the organization. \\
\hline Asv5 & $\begin{array}{l}\text { Improvement plans for high-level processes exist and are driven by customer and operating } \\
\text { strategies. }\end{array}$ \\
\hline Addp1 & Core and supporting business processes are clearly defined in our organization. \\
\hline Addp2 & Processes within our organization are documented with clearly defined inputs and outputs. \\
\hline Addp3 & Process roles and responsibilities are clearly defined and documented. \\
\hline Addp4 & $\begin{array}{l}\text { Processes within our organization are defined so that most people in the organization know how they } \\
\text { work. }\end{array}$ \\
\hline Addp5 & Business process descriptions (models) are available to every employee in the company. \\
\hline Addp6 & Our organization uses a standardized methodology for describing business processes. \\
\hline Ammp1 & Process measures are defined and documented for each process. \\
\hline Ammp2 & Process performance is measured in the organization. \\
\hline Ammp3 & Performance targets are used for each process goal. \\
\hline Ammp4 & Performance indicators are communicated within the organization on a regular basis. \\
\hline Ammp5 & Performance results are used in setting improvement targets. \\
\hline Ammp6 & Changes to processes must go through a formal change process. \\
\hline Ammp7 & Process changes are communicated to all appropriate stakeholders. \\
\hline Apos1 & Jobs are usually multidimensional and not just simple tasks. \\
\hline Apos2 & The organizational structure supports seamless execution of processes across departments. \\
\hline Apos3 & Employees often work in teams consisting of people from different departments. \\
\hline Apos4 & Process ownership is defined and established. \\
\hline Apos5 & Process owners are at the same hierarchal level as functional managers. \\
\hline Apos6 & $\begin{array}{l}\text { At what hierarchal level is the person responsible for business processes (e.g., the chief process } \\
\text { officer)? (Member of top management; directly under top management; lower level of management; } \\
\text { we do not have a person responsible for business processes). }\end{array}$ \\
\hline Apos7 & $\begin{array}{l}\text { How is process management (responsibility for process documentation, administering process } \\
\text { improvements, documenting changes, etc.) structured in your organization? (We have a dedicated } \\
\text { organizational unit; process management is a part of wider organizational unit; selected individuals are } \\
\text { responsible for process management; in no form) }\end{array}$ \\
\hline Auk1 & Employees are constantly learning new things on the job. \\
\hline Auk2 & Employees are trained in business process improvement methods and techniques. \\
\hline Auk3 & People are trained to operate new or changed processes prior to implementation. \\
\hline Auk4 & Employees are held accountable for delivering on business process goals. \\
\hline
\end{tabular}




\begin{tabular}{|c|c|}
\hline Auk5 & Employees' creative talents are stimulated in incremental and breakthrough improvements. \\
\hline Apok1 & $\begin{array}{l}\text { Process terms such as input, output, process, and process owners are used in conversations in the } \\
\text { organization. }\end{array}$ \\
\hline Apok2 & The average employee views the business as a series of linked processes. \\
\hline Apok3 & When members of several departments get together, tensions frequently run high. \\
\hline Apok4 & Employees from different departments feel that the goals of their departments are aligned. \\
\hline Apok5 & $\begin{array}{l}\text { Managers from different departments regularly have meetings to discuss business process-related } \\
\text { issues. }\end{array}$ \\
\hline Apok6 & People from different departments feel comfortable consulting each other when the need arises. \\
\hline Atu1 & Our organization carries out market studies to determine its customers' needs and wants. \\
\hline Atu2 & Employees understand what product characteristics customers value most. \\
\hline Atu3 & Feedback received from customers is used systematically in improvement of internal processes. \\
\hline Atu4 & Our organization measures customer satisfaction systematically and frequently. \\
\hline Atu5 & Products and services are designed and developed based on customer needs and expectations. \\
\hline Atu6 & We monitor our competitors' activities. \\
\hline Atu7 & We rapidly respond to competitors' actions. \\
\hline Avd1 & Our organization is partnering (i.e., establishing a long-term relationship) with its key suppliers. \\
\hline Avd2 & Our organization works in close collaboration with suppliers to improve processes. \\
\hline Avd3 & Changes to our business processes are formally communicated to our suppliers. \\
\hline Apip1 & IS design and development is process based. \\
\hline Apip2 & $\begin{array}{l}\text { Our information systems provide relevant management information on the performance of our } \\
\text { organization's business processes. }\end{array}$ \\
\hline Apip3 & IT systems are flexible and are able to adapt to the needs of process changes. \\
\hline Apip4 & Our organization uses a CRM system to manage customer relationships. \\
\hline Apip5 & $\begin{array}{l}\text { E-procurement, EDI, or another type of SCM is implemented to connect our organization with } \\
\text { suppliers. }\end{array}$ \\
\hline Apip6 & Our organization has deployed a complete document management system. \\
\hline Apip7 & Our organization has deployed a complete business process management system. \\
\hline
\end{tabular}

Mojca Indihar Štemberger is an Associate Professor of information management at the Faculty of Economics, University of Ljubljana, Slovenia. Her research interests encompass business process management, e-business and decision support systems. She received her Master in Computer and Information Science degree in 1996, and her $\mathrm{PhD}$ in Information Science in 2000 from the University of Ljubljana. Dr Indihar Štemberger has published several scientifc and professional papers. She has been a consultant for business process change on several projects in the public and private sectors. Since 2001 she has been president of the Slovenian information management conference and she was conference chair of the InSITE 2007 conference.

Vesna Bosilj Vukšić is a professor of Business Process Management, Simulation Modelling and Business Computing at the Faculty of Economics and Business, University of Zagreb. Her current research interests are in business process management and information systems development. She participates actively in research within the framework of the Ministry of Science and Technology's scientific projects, she is a leader of the project "Information, process and knowledge management systems" funded from the Croatian Ministry of Science, Education and Sports" (2007-) and is a member of international s cientific research projects. Vesna Bosilj Vuksic has been a consultant for business process change on several projects in public and private sector.

Phd. Rok Škrinjar is a teaching assistant at the Faculty of Economics, University of Ljubljana, Slovenia. His research interests include business process redesign, business process management and process orientation and their impact on organizational performance. He has published several scientific and professional papers on this subject. He has worked on many consulting project in the field of process modeling and redesign in different industries. 